\author{
C. B. Aлnатов \\ МГУ им. М. В. Ломоносова, Москва, Россия. alpserg@gmail.com \\ В. Г. Ченцова \\ UMR 8167 «Восток и Средиземноморье / Византийский мир» Париж / Maison \\ franzaise d'Oxford. graougraou@hotmail.com

\section{РУССКИЙ ПЕРЕВОД ПАПСКОГО БРЕВЕ 1672 г. ОБ ОБЪЯВЛЕНИИ ЮБИЛЕЙНОГО ГОДА}

\begin{abstract}
В статье рассмотрены исторический контекст издания папского бреве 1672 г., возможные пути его распространения в Восточной Европе, политическое значение документа для формирования антиосманской коалиџии, а также лингвистические особенности русского перевода латинского текста.

Ключевые слова: бреве, юбилейный год, папа Климент X, русский перевод, османское завоевание КамениаПодольского
\end{abstract}

Обнаруженный в фондах РГАДА (Ф. 155. Оп. 1. № 7. 1672 г.) текст русского перевода бреве «Jubilaeum universale ad implorandam divinam opem contra Turcas» папы Климента X (1670-1676 г.), датированного 5 ноября 1672 г., был восстановлен из некогда разрозненных и перемешанных при расклейке столбџа листов (при этом последовательность фрагментов была выстроена не совсем точно), текстологически, исторически и лексикологически откомментирован и опубликован И. А. Корнилаевой, А. В. Кузнешовой, С. М. Шаминым [Корнилаева, Кузнецова, Шамин]'. Этот документ интересен как с точки зрения изучения переводческой практики в Московском государстве XVII в. (языковых механизмов перевода и интерпретаџии переводчиком конфессиональных терминов и культурных реалий), так и в связи с исследованием дипломатии русского двора, его вовлеченности в противостояние западных государств с Османской империей и проходивших в это время переговоров с папской курией и Речью Посполитой.

Издание папского бреве ${ }^{2}$ стало ответом на захват османскими войсками в августе 1672 г. Каменџа-Подольского и заключение в октябре того же года польским королем Михаилом Корибутом Вишневеџким Бучачского мира, по которому значительные территории Подолья переходили под османский контроль [Kołodziejczyk, 1994, s. 45-85; Ф Kołodziejczyk, 2004, p. 3-10; Davies, p. 156-157; Wagner, p. 215-307; Ostapchuk, p. 144-146; С поддержку Польско-Литовскому государству объявлением экстраординарного «юбилейного года» [Усков] с призывом к борьбе против османского наступления 3 . В соответствии с грамотой, в наступаюшем году папа Климент $\mathrm{X}$ провозглашал прошение грехов и дарование благодати всем католикам, которые будут молиться об одолении врага. Надежды курии на упрочение единства польско-литовского общества ради противостояния Османской державе также нашли отражение в тексте бреве: в нем говорилось, что христианская молитва должна «согласить» души «поляков» (Polonorum animos dissidiis distractos reconciliare), ведь одной из причин поражения

\footnotetext{
1 Далее при ссылках на издание текста документа используется сокрашение: Грамота 1672. О спеџифике формуляра папских бреве см.: [ᄉихачев].

2 Tamburini Th. Moralis explicatio... accedit tractatus Bullae cruciatae. Venetiis, 1719. P. 46-47 (второй нумераџии); Magnum Bullarium romanum, a beato Leone Magno usque ad S. D. N. Benedictum XIII. Luxemburgi, 1727. Vol. 6: Ab Alexandro VII. ad Clementem X / Ed. L. Cherubini. Appendix. P. 34-36 (= Luxemburgi, 1742); Bullarum, diplomatum et privilegiorum sanctorum Romanorum pontificum Taurinensis editio, locupletior facta / Cura et studio A. Tomassetti [Ed. M. Marocco]. Turin [Augusta Taurinorum], 1869. Т. 18. № 120. Р. 364-367. Далее ссылки даются на издание 1869 г., обозначаемое: Breve 1672.

3 Папа Климент X, таким образом, провозгласил 46-й внеочередной юбилейный год спустя всего два года после предыдушего, объявленного им в связи со своим избранием на папский престол: [Thurston, $\rho .391]$.
}

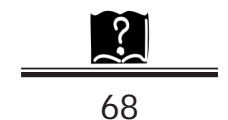


под Каменџом стали внутренние конфликты в польско-литовском обществе ${ }^{4}$. Если бы Господь, умилосердившись, даровал «истинное соединение» (veram concordiam) христианам, они смогли бы одержать победу.

Возможность получения индульгенџии имели не только католики, находившиеся в $\rho_{\text {име }}$ и, в соответствии с традиџией, принятой для «юбилейных лет», обязанные для этого посетить главные базилики «Города» - Латеранскую (џерковь «святаго Иоанна в Латеранне»), собор Св. Петра и базилику Св. Павла «fuori le Mura» (обозначенные в латинском тексте как «Principis Apostolorum», что переводчиком было понято в единственном числе: «верховнаго апостола»), базилику Санта-Мария-Маджоре («Святыя Марии величайших џерквей» $)^{5}$ ), а также принявшие участие в крестном ходе от џеркви Санта-Мария-сопра-Минерва («святыя Марии над Минервою имянованныя») до церкви Санто-Станислао-деи-Полакки («церкви святаго Станислава рода поляхов» ${ }^{6}$. Отпушение грехов в этот раз могли получить и христиане, приходящие в соборные

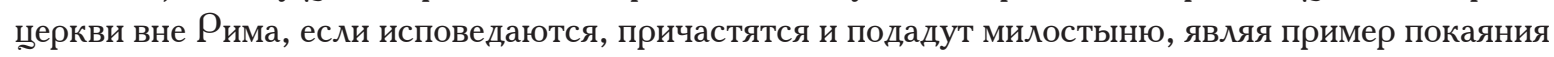
и единения в молитве перед общей опасностью от «презлых врагов христианского имени» (infensissimorum christiani nominis hostium) - султана и его войска.

Озабоченность османской экспансией и стремление вдохновитьпольского короля отказаться

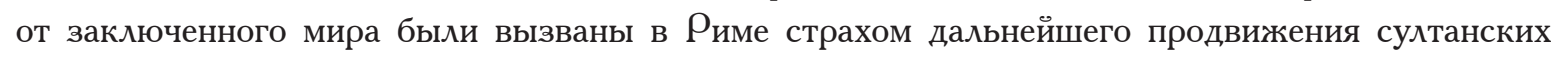
войск в Италию. Важная роль в папской дипломатии этого времени была отведена архиепископу

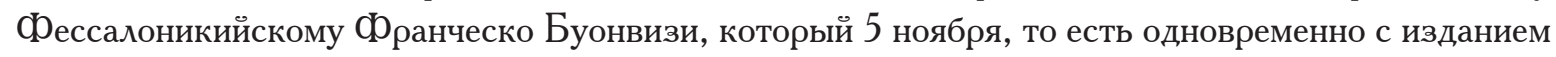
бреве, был назначен экстраординарным нунџием при польском дворе ${ }^{7}$. Уже в ноябре 1672 г.

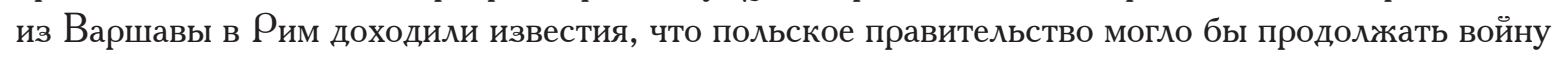
в случае поддержки его союзниками, прежде всего императором Леопольдом и московским џарем [Чарыков, с. 123-125, № 40]. В это время Буонвизи еше находился в Кельне, ожидая бреве с утверждением его в роли папского посланџа. В начале декабря он позаботился о перепечатке и последуюшей рассылке полученного им бреве о юбилее по епископским диоџезам, выразив надежду в написанном тогда письме к близкому папе кардиналу Палюџџи-Алтьери дельи Албертони, что Господь придет к христианам на помощь 8 . Уже 20 декабря 1672 г. в Зальџбурге в виде листовки был опубликован немеџкий перевод (с сокрашениями) текста бреве: экземпляр издания, о котором, по-видимому, и упоминал нунџий в письме, сохранился в Наџиональной библиотеке Шотландии в Эдинбурге9.

Когда в начале 1673 г. Буонвизи прибыл сначала в Вену, а затем в Варшаву, он продолжил уже начатую ранее деятельность по консолидаџии сил союзников (в том числе обеспечивая финансовую поддержку польскому правительству) и по примирению с королем польской «партии недовольных» ${ }^{10}$, возглавляемой великим коронным гетманом Яном Собеским, ради достижения

\footnotetext{
4 Breve 1672. P. 365.

5 Здесь «величайших» на самом деле должно было относиться собственно к џеркви «Святыя Марии», однако ошибка или описка переводчика исказили название римской базилики. См. также указание места составления грамоты в переводе: «во святыя Марии величайшие» (Грамота 1672. С. 146).

6 Џерковь стала храмом «поляков» с конџа XVI в., когда по указу папы Григория XIII была передана известному польскому богослову, кардиналу Станиславу Гозию, который перестроил ее и посвятил св. епископу Станиславу Шепановскому, покровителю Польши.

7 [Trevellini, p. 3-4]; Buonvisi Fr. Nunziatura a Colonia / A cura di F. Diaz. Roma, 1959. Vol. 2: 1 gennaio $1672-$ 31 dicembre 1672. (Istituto storico italiano per l'età moderna e contemporanea. Fonti per la storia d'Italia. Vol. 37). № 991. P. 391.

${ }^{8}$ Buonvisi Fr. Nunziatura a Colonia. № 1022. P. 416: «Ho fatto ristampare la bolla del giubileo, el’ho mandata a i vescovi che la facciano pubblicare nelle loro diocesi...».

9 National Library of Scotland. Special Collections Reading Room. Crawford. B. 24 (125). Сердечно благодарим Д. Уо (Вашингтон) за указание этого издания перевода бреве и места его хранения.

10. Buonvisi Fr. Nunziatura a Varsavia / A cura di F. Diaz e N. Carranza. Roma, 1965. Vol. 1: 3 gennaio 1673 - 2 giugno 1674. (Istituto storico italiano per l'età moderna e contemporanea. Fonti per la storia d'Italia. Vol. 75). P. 125-143.
} 


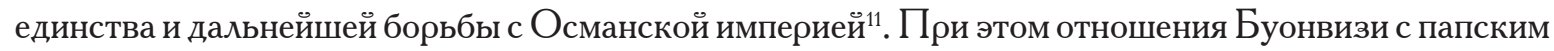
нунџием Анджело Мария Рануџџи оказались весьма сложными и были урегулированы лишь летом, когда он сам, несмотря на недовольство польского короля, предпочитавшего ему Рануџџи, получил назначение заменить последнего в качестве ординарного нунџия в Варшаве ${ }^{12}$. Тогда же,

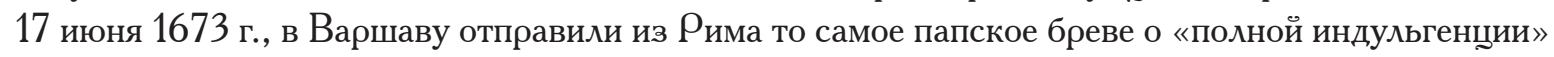
(breve della Indulgenza plenaria), в «соответствии с желанием короля» разрешающей от грехов всех воинов, «которые погибнут на войне с турками во время кампании этого года» [Чарыков, c. 166-167, № 88]. Возможно, речь шла о новом тираже листовки. Примирение враждуюших партий в Речи Посполитой и финансовая поддержка со стороны курии и союзников должны были подкрепляться всеобщей молитвой и разрешением грехов: все было готово к продолжению войны с Портой.

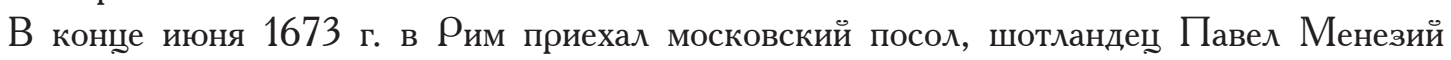
[Чарыков, с. 172, № 95]. Московский двор также проявлял заинтересованность в совместной борьбе с османами, приблизившимися к граниџам Московского государства и представлявшими опасность для находяшейся под шарским контролем Левобережной Украины [Флоря, 2001,

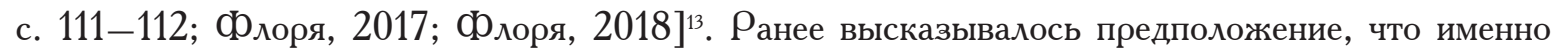

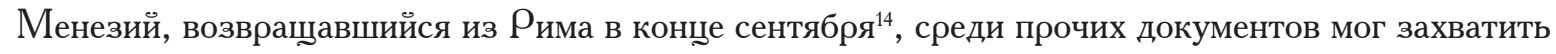
в Москву и текст папского бреве об отпушении грехов [Корнилаева, Кузнецова, Шамин, c. 129]. Однако более вероятной кажется доставка документа с пересылаемыми тогда в Москву многочисленными вестовыми письмами и европейскими газетами, тщательно изучаемыми и переводимыми в Посольском приказе. Примечательно, что дипломатическая деятельность римской курии, особенно посланџев папы в Польско-Литовское государство, весьма часто упоминается в этих известиях ${ }^{15}$.

Интерес к сведениям о вовлеченности понтифика в европейские события проявлял иотправленный из Москвы в 1672 г. в дипломатическую поездку по европейским странам Андрей Виниус. Переводчик Посольского приказа, сын голландского купџа, обосновавшегося в русской столиџе, он должен был выяснить готовность европейских правителей к антиосманскому союзу с Московским государством [Шамин, 2011, с. 279]. Для получения свежих новостей о международной политике Виниус поддерживал контакты с разными информаторами, среди которых важную роль играл почтмейстер Даниил Брандес, живший в Гданьске и снабжавший Посольский приказ газетами. Как раз в конџе 1672 г. Брандес сообџал московскому посланџу о приезде «в Полшу» некоего «посла» папы (вероятно, речь идет о Буонвизи), который намерен был примирить короля с оппозиџией и обешал финансовую поддержку польской короне ${ }^{16}$. Видимо, не случайно «Перевод с латинского писма, каково писал папа римский ко всем католиком» оказался среди русских переводов с курантов и разнообразных «печатных листков», памфлетов

11 [Petrocchi, p. 91-92; Trevellini, р. 3-4]. См. также письма Буонвизи из Вены и Варшавы, посланные в Рим в начале 1673 г.: Buonvisi Fr. Nunziatura a Varsavia. P. 90-95, 98-103, 107-143, 146-155, 159-166; Litterae nuntiorum apostolicorum historiam Ucrainae illustrantes (1550-1850). Romae, 1968. Vol. XII: 1670-1674 / Ed. P. Athanasius G. Welykyj. P. 244-252.

${ }_{12}$ См., например: Buonvisi Fr. Nunziatura a Varsavia. P. 222-223, 225-226, 235, 244, 248-249, $252-253$.

${ }^{13}$ В это же время, в начале 1673 г., Посольский приказ начал вести переговоры с правобережным гетманом Петром Дорошенко, султанским вассалом, убеждая его перейти на сторону џаря с тем, чтобы установить контроль над ранее принадлежавшими Польско- Литовскому государству украинскими землями. Эти переговоры, приведшие в конечном счете к сдаче Дорошенко и принятию им московского подданства, не могли не обеспокоить предполагавшихся союзников - польский и габсбургский дворы, а также римскую курию: Litterae nuntiorum apostolicorum. Vol. XII. P. 252 .

${ }_{14}$ Buonvisi Fr. Nunziatura a Varsavia. P. 352-353.

15 Вести-Куранты. 1671-1672 гг. / Подг. текстов, иссл., коммент. И. Майер, С. М. Шамина, А. В. Кузнеџовой, И. А. Корнилаевой, В. Б. Крысько, при участии Е. В. Амановой. М., 2017. С. 94-95, 98, 103-108, 115, 118, 128, 136-137, 153-154, 160-161, 170-177, 188, 193-194, 204, 211, 235, 243, 247, 256, 337.

16 «...И против турка обешал великую казну. К тому ж и во всех окрестных государствах будушим послом своим просит на турка помоши с великим усердием» (Вести-Куранты. 1671-1672 гг. С. 337).

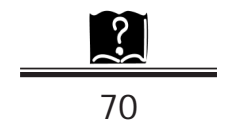


и в том числе «грамоток», написанных к «Андрюшке Виниусу» от его агентов-информаторов ${ }^{17}$.

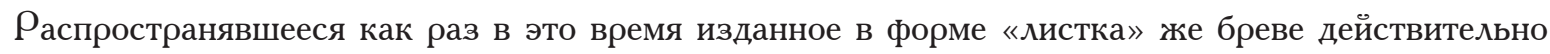
могли, скорее всего, доставить через почту вместе с газетами (от Брандеса или какого-то иного агента).

В ноябре 1673 г. произошло два важных события, не только обеспечивших победу сторонников продолжения войны в Речи Посполитой, но и оказавших сушественное воздействие на международную политику: польский король Михаил Корибут Вишневеџкий скончался, а командующий войсками Ян Собеский нанес первое значительное поражение османским войскам под Хотином и поспешил отправить захваченные султанские знамена папе ${ }^{18}$. C называемым не иначе как «позорным» миром было покончено, и позже, в мае 1674 г., пользуюшийся большой популярностью герой антиосманской борьбы был избран польским королем. Этот первый значительный успех возродил надежды на освобождение от туреџкого владычества в румынских землях. Не удивительно, что уже в начале 1674 г. в Москву приехал игумен афонского монастыря Агиу Павлу Феодор с письмами от румынских владетелей, призываюшими Московское государство на помощь в борьбе с султаном ${ }^{19}$. Одно из писем было из Ясс от двух господарей - бывшего валашского воеводы Константина Щербана, проведшего долгое время в изгнании в Польско-Литовском государстве, и от тогдашнего молдавского правителя Штефана Петричейку ${ }^{20}$.

В письме, сообщаюшем о победе Яна Собеского под Хотином, высказывалась просьба избавить покоренных султаном христиан от «работы поганские» и «порабошения бусурманского» и выражалось намерение обоих господарей перейти в џарское подданство. Примечательно, что в тексте послания можно увидеть аллюзию на папское бреве, наверняка известное в их окружении. В его русском переводе неоднократно встречаются выражения, характеризуюшие «лакомство» и «ненасытность» врагов: отправители письма обращались с жалобой из-за «многих неправд, которые терпим от несытных поган, зане имеюще они прескверное лакомство, отринули нас от всех древних обычаев, которыми в древних временах с ними договаривали»; румынские государства оказались в тяжелом положении, поскольку «поганя», «по скверному их лакомству хотяще простирати владение свое и покорити и Польскую землю», вынудили христиан обеспечивать османское войско запасами и таким образом «овладели Каменеџ и иные многие уезды в Польской земле с крепостями» ${ }^{21}$. Относительно же возможной судьбы Молдавии и Валахии в том случае, если наступление османских войск будет продолжено, говорилось: «И буде возмет бусурманин сия два господарства, по их прескверному лакомству будут желать и больши разпространятись, зане и сими двемя господарствы великая ему сила прибавляется» ${ }^{22}$. Эти описания «лакомства» и «желания» «бусурман» перекликаются с рассматриваемым нами переводом папской грамоты, в котором взятие Каменџа-Подольского также объясняется следствием «несытного... желания» султана, «чрез него же желает владети и желания своего пределы роспространити» ${ }^{23}$, и, разумеется, с подлинным текстом бреве: «...pro inexplebili, qua flagarat, dominandi imperiique sui pomoeria proferendi libidine, victricia... $\gg^{24}$. Не исключено, таким образом, что папское бреве было известно также в политических кругах православного мира

17 Вести-Куранты. 1671-1672 гг. С. 16-17.

18 [Corsi, ९. 26]; Buonvisi Fr. Nunziatura a Varsavia. P. 415.

19 О надеждах в Трансильвании, Молдавии и Валахии «сбросить иго» и участвовать в антиосманском союзе писал тогда и папский нунџий Буонвизи: Litterae nuntiorum apostolicorum. Vol. XII. P. 247.

20 Подлинник письма на румынском языке с переводом: Исторические связи народов СССР и Румынии в XV начале XVIII в. М., 1970. Т. 3. С. 9-16. № 1. См. также: РГАДА. Ф. 52. Оп. 1.1674 г. Д. 1. ․ 1-11.

21 Исторические связи народов СССР и Румынии. Т. 3. С. 13. См. также: РГАДА. Ф. 52. Оп. 1. 1674 г. Д. 1. ᄉ. 1 (текст следует после л. 3), 3-4. С . и письмо Константина Шербана: «по прескверном их лакомстве и еше и больши разширятись будут...» (Там же. $ᄉ .45)$.

22 РГАДА. Ф. 52. Оп. 1. 1674 г. Д. 1. А. 7.

${ }^{23}$ Грамота 1672. С. 141.

24 Breve 1672. P. 364. 
среди сторонников борьбы с Османской империей и союза с Польско-Литовским государством и могло попасть в Москву через их посредство 25.

Очевидная популярность юбилейного папского бреве 5 ноября 1672 г., равно как и выявленные параллели в топике синхронных ему восточноевропейских антиосманских текстов, побуждают внимательнее присмотреться к содержанию русского перевода папской грамоты, а также оценить принџипы и результаты работы переводчиков Посольского приказа.

Сопоставление подлинного латинского текста папского бреве с русским переводом, с одной стороны, подтвердило тот факт, что хранящийся в РГАДА перевод сделан с полного издания (либо списка) латинского текста папской грамоты (а не с текста, подобного сокрашенной немеџкой листовке, изданной в Зальџбурге 20 декабря 1672 г., где вместо перевода параграфов 10-12 латинского оригинала стоит: «Non obstantibus \&c.»); с другой стороны, позволило окончательно установить порядок листов рукописи перевода: л. 32-33, 235-236, 247, 249 , 248, 237-238, 246, 239-245.

Говоря об особенностях перевода и принџипах работы переводчика, следует отметить ряд черт анализируемого текста.

Прежде всего, русский текст не является подстрочником. Переводчик сравнительно свободно обрашается с синтаксисом оригинала, сохраняя исходную предикативную схему с глаголами в конџе фразовых отрезков, но перестраивая при необходимости порядок второстепенных членов предложения:

...immitis Turcarum tyrannus, eo successu inflatus pro inexplebili, qua flagarat, dominandi imperiique sui pomoeria proferendi libidine, victricia arma quaquaversum circumferre, arces, oppida, civitates et provincias debellare, populos servitute opprimere, et miserandam in captivitatem adducere (Breve 1672. P. 364). ...неутолимый турский тиран счастием сим возгордевшеся ради несытного своего желания, чрез него же желает владети и желания своего пределы роспространити, победителное оружие во всех странах окрест принести, замки, городы, села, и страны пленити, народы работою понудить, и во плачное пленение привести (Грамота 1672. С. 141).

Конструкџию ablativus absolutus он закономерно передает с помошью «дательного самостоятельного»: «Expugnata siquidem nuper Cameneciб» - «зане недавно плененну бывшему Каменџу Подолскому».

Латинскую конструкџию из наречия и герундива он переводит конструкџией инфинитив + наречие, не совсем успешно справляясь с модальностью долженствования:

\begin{tabular}{|c|c|c|}
\hline Breve 1672 & Грамота 1672 & Подстрочник \\
\hline $\begin{array}{l}\text {...paterne requirimus, monemus et } \\
\text { hortamur ad infrascripta devote } \\
\text { peragendum, ac Deum salvatorem } \\
\text { nostrum toto corde orandum... } \\
\text { (Breve } 1672.9 .364 \text { ). }\end{array}$ & $\begin{array}{l}\text {...яко отџы просим, увещеваем, } \\
\text { и подвижаем сотворити } \\
\text { нижеписанная благочестиво, и } \\
\text { к Богу Спасителю нашему все } \\
\text { сердуе молително... (Грамота } \\
\text { 1672. С. 144). }\end{array}$ & $\begin{array}{l}\text { Отечески настаиваем, } \\
\text { увещеваем и убеждаем, что } \\
\text { ниженаписанное должно быть } \\
\text { благочестиво совершено и к Богу } \\
\text { Спасителю нашему должно всем } \\
\text { сердџем помолиться (букв.: } \\
\text { «должно быть от всего сердџа } \\
\text { помолено»). }\end{array}$ \\
\hline
\end{tabular}

Отдельную проблему для исследователя представляет интерпретация случаев употребления переводчиком неверных с точки зрения русского языка падежей. Сушествует два основных

25 См. о такого рода известиях, поступаюших в Москву от православных информаторов: [Шамин, 2009 ]. 
механизма возникновения подобных ошибок. Во-первых, это калькирование при переводе падежных форм латинского оригинала, например:

фраза «Святейшаго господина нашего Климента, Божиею предсмотрению Папы Десятого» калькирует окончания аблатива 1-го склонения женского рода divina providentia;

в предложении «аше неправды наши, им же его зело досадили» неверное управление («досадили его» вместо «ему») обусловлено калькой местоименного аккузатива eum;

в аллюзии на обшеизвестное место из Книги пророка Иезекииля (33: 11) «иже не хошеть смерть грешника, во еже возвратитися и жив быти» дефектные формы винительного и именительного падежей вместо корректных родительного и дательного (ср. «яко не хощу смерти грешника, но якоже обратитися ему и живу быти ему» (Московская Библия 1663 г.)) передают аккузатив и форму 3-го лиџа глагола латинского оригинала: «qui non vult mortem peccatoris, sed ut magis convertatur et vivat»;

возникновение нелепого окончания «Отџа милосердиях, и Бога всякого утешения согласно призовем» может быть объяснено попыткой улучшить корректную русскую конструкџию «Отџа милосердия и Бога утешения» за счет восстановления множественного числа оригинала: «Patrem misericordiarum et Deum totius consolationis concorditer invocemus» - *Отца милосердий / *Отца милосердиям $>$ «Отџа милосердиях».

Во-вторых, дефектные падежные формы возникают при потере смысловой связи с управляюшим словом при переводе вставных конструкџий и придаточных предложений. Например, предложение «и сердџа нашего сокрушенного жертвы, и молитвы наши, постом и милостынею, силою покрепленых, яко кадило во благоухание над олтарем его приносим» корректно можно перевести так: «и жертвы нашего сокрушенного сердџа, и наши молитвы, силою поста и милостыни подкрепленные, приносим как кадило во благоухание над алтарем Его» (или букв. «постов и милостынь силами подкрепленные» - в соответствии с множественным числом форм оригинала: «ieiuniorum atque eleemosynarum viribus roboratas»).

Проведенные ранее наблюдения над словарным составом текста перевода позволили установить, что за исключением нескольких редких, вариативных и экзотических лексем язык и стиль перевода не сильно отличается от языка стандартных документов приказного регистра [Корнилаева, Кузнеџова, Шамин, с. 134-136]. Добавим, что џерковные должности, географические и административные термины переведены последовательно с учетом стандартной для бумаг Посольского приказа номенклатуры:

Quapropter tenore praesentium, in virtute sanctae obediendiae districte praecipimus atque mandamus omnibus et quibuscumque venerabilibus fratribus patriarchis, archiepiscopis, episcopis, et aliis ecclesiarum praelatis, ac quibuscumque Ordinariis locorum, ubicumque existentibus, eorumque vicariis et officialibus, vel, his deficientibus, iis qui curam animarum exercent... (Breve 1672. P. 366).

...una cum venerabilibus fratribus nostris S. R. E. cardinalibus, necnon patriarchis, archiepiscopis et episcopis, quos in Romana Curia adesse contigerit, ac christianorum regum et principum oratoribus apud nos existentibus, praelatis quoque et officialibus eiusdem Curiae, universoque clero et populo... (Breve 1672. P. 365).
Сего ради сим настояшим силою святаго послушания известно повелеваем и подвижаем всем обше, и особно честным братиям, патриархом, архиепископом, епископом и иным џерковным начальником и всем чином повсюду сушим, и их наместником и начальником, или без них, их иже в душах попечение имеют... (Грамота 1672. C. 145).

...вместе с пречестными братьи нашими святыя Римские џеркве кардиналы и патриархи, архиепископы и епископы, имже прилучилось пребывати в римской полате, и христианных кролей и владетелей послы к нам сушим, иигумены, и начальники тое ж полаты, и весь клир и народ... (Грамота 1672. С. 142). 


\begin{tabular}{|l|l|}
\hline $\begin{array}{l}\text {...qui ecclesias ab Ordinariis locorum, vel eorum } \\
\text { vicariis seu officialibus, aut de eorum mandato, et, ipsis } \\
\text { deficientibus, per eos, qui ibi curam animarum exercent... } \\
\text { (Breve 1672. P. 365). }\end{array}$ & $\begin{array}{l}\text { прочим же, вне вышереченнаго града повсюду } \\
\text { пребываюшим, иже џеркви от начальных мест или их } \\
\text { суть чрез повеление их, или чрез них, иже попечение } \\
\text { душах имеют (Грамота 1672. С. 142-143). }\end{array}$ \\
\hline $\begin{array}{l}\text { arces, oppida, civitates et provincias debellare (Breve } \\
\text { 1672. P. 364). }\end{array}$ & $\begin{array}{l}\text { замки, городы, села и страны пленити (Грамота } 1672 . \\
\text { С. 141). }\end{array}$ \\
$\begin{array}{l}\text { per suas ecclesias et dioeceses, provincias, civitates, } \\
\text { oppida, terras et loca (Breve 1672. P.366-367). }\end{array}$ & $\begin{array}{l}\text { чрез свои страны и џеркви, места, грады, села и земли } \\
\text { (Грамота 1672. С. 145). }\end{array}$ \\
\hline
\end{tabular}

Известные трудности для читателей перевода могли представлять варианты передачи названия Польского государства, совпадаюшие полностью или частично с наименованиями христианских земель / џерковного сообщества в џелом:

\begin{tabular}{|c|c|}
\hline $\begin{array}{l}\text {...de florentissimi olim Poloniae regni... Quis enim, } \\
\text { aliquo honoris Dei zelo atque pietatis sensu praeditus, in } \\
\text { luctuosam tam potentis tantaque rerum pro christiana } \\
\text { religione fortiter gestarum gloria longe lateque fulgentis } \\
\text { regni faciem mentis oculos absque lacrymis coniicere } \\
\text { possit? Quis, ad gravissima quae universae christianae } \\
\text { reipublicae imminent pericula, non expavescat? ... } \\
\text { totamque rempublicam christianam (Breve } 1672 \text {. } \\
\text { P. } 364 \text { ). }\end{array}$ & $\begin{array}{l}\text { О древле благополучнейшего кролевства Польского } \\
\text { делех... Кто убо воздарован ревностию чести Божией } \\
\text { и благочестивым умом, может без слез возвести очи } \\
\text { свои умные к лиџу королевства сиџеваго сияюшаго, } \\
\text { широко и пространно сиџе силнаго, и в толикой славе } \\
\text { делем християнства Речи Посполитой ради прежде } \\
\text { делавшаго; кто не ужаснется о тежчайших бедах, } \\
\text { яже ко всякой християнской Речи Посполитой } \\
\text { приближаются... всякий народ христианский } \\
\text { (Грамота } 1672 . \text { С. } 140-141) \text {. }\end{array}$ \\
\hline $\begin{array}{l}\text { suae religionem christianam fidemque catholicam tueri } \\
\text { (Breve 1672. P. 365). }\end{array}$ & $\begin{array}{l}\text { благочестие христианское, и веру католическую } \\
\text { хранити (Грамота 1672. С. 144). }\end{array}$ \\
\hline
\end{tabular}

Определенные затруднения вызвал перевод частных конфессиональных понятий и терминов:

\begin{tabular}{|c|c|c|}
\hline Breve 1672 & Грамота 1672 & Подстрочник \\
\hline $\begin{array}{l}\text { Et insuper vota quaecumque } \\
\text { (religionis et castitatis exceptis) } \\
\text { in alia pia et salutaria opera (Breve } \\
\text { 1672. P. 366). }\end{array}$ & $\begin{array}{l}\text { притом и обешания, каковыя будут } \\
\text { [кроме вера и уеломудрие] во } \\
\text { иных благочестивых и спасителных } \\
\text { делех (Грамота 1672. С. 144). }\end{array}$ & $\begin{array}{l}\text { Притом и обешания, какие } \\
\text { будут кроме обетов благочестия } \\
\text { и воздержания (возможно, } \\
\text { монашеских и безбрачия. }- \text { C. A., } \\
B . \text { Ч.) в иных благочестивых и } \\
\text { спасительных делах. }\end{array}$ \\
\hline $\begin{array}{l}\text { Quibus omnibus et singulis etiamsi } \\
\text { de illis eorumque totis tenoribus } \\
\text { specialis, specifica et expressa et } \\
\text { individua, non autem per clausulas } \\
\text { generales idem importantes (Breve } \\
\text { 1672. P. 367). }\end{array}$ & $\begin{array}{l}\text { В сим всем обџе и особне, аше и } \\
\text { о них особное писмо будет и явное, } \\
\text { ниже будут чрез колы }{ }^{26} \text { соборные } \\
\text { тожде знаменуюше (Грамота } 1672 . \\
\text { С. } 146) .\end{array}$ & $\begin{array}{l}\text { Обо всех вообше и о каждом } \\
\text { отдельно будут полные особые } \\
\text { постановления, конкретные, } \\
\text { определенные и персональные, } \\
\text { или через общие положения то же } \\
\text { гласящие (возможно, соборные } \\
\text { постановления. - С. А., В. Ч.). }\end{array}$ \\
\hline
\end{tabular}

26 «Коло» - одно из значений слова: 'совет, собор, совещание' (см.: Словарь русского языка XI-XVII вв. M., 1980. Вып. 7. С. 242-243; Шетэля В. С. Словарь полонизмов русских текстов XIX-XX веков. М., 2019. C. 127-128).

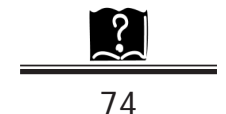


В ряде случаев сложный синтаксис латинского оригинала вынуждает переводчика, теряющего логическую нить в развернутом риторическом периоде, опускаться до пословного перевода, что закономерно приводит к радикальным потерям грамматической связности и смысла высказывания в џелом:

\begin{tabular}{|l|l|l|}
\hline Breve 1672 & Грамота 1672 & Подстрочник \\
\hline ...ac Mahumetanae perfidiae & $\ldots$ магметскою неверностию & $\ldots$ оияватительным \\
abominationem, vi, terrore, & мерзость силою, страхом, & магометанским вероломством, \\
dolo, omnique conatu in agro & лукавою, и всякому понуждению & насилием, страхом, лукавством \\
Dei viventis plantare non & в ниве Бога живущаго сеяти & всякие беды сеять на ниве Бога \\
cessat, totamque rempublicam & не престанет, и всякий народ & живаго не престает и всякой \\
christianam clade involvere & христианский радеет смешати & земле христианской нанести \\
molitur (Breve 1672. P. 364). & убиением (Грамота 1672. & вред стремится. \\
& С.141). & \\
\hline
\end{tabular}

В џелом уверенно владея разнообразной латинской лексикой, переводчик вместе с тем регулярно использует излюбленные русские формулы и конструкџии, в частности, многие выражения оригинала он передает с помошью figura etymologica:

\begin{tabular}{|l|l|}
\hline dissidiis distractos reconciliare & растерзаны несогласием согласити \\
\hline firmiter solidare & крепко покрепити \\
\hline firmisque praesidiis munire & крепким хранением покрепит \\
\hline quavis firmitate alia roboratis & иным каким подкреплением подкрепленым \\
\hline fideles suos fortiter vinciat concordiae nexu & $\begin{array}{l}\text { да присвязает верных своих крепко связанием } \\
\text { согласия }\end{array}$ \\
\hline atque a christianorum cervicibus longe repellant & да одалеет далече от выя христианов \\
\hline
\end{tabular}

Особо следует сказать о переводе библейской џитаты из Книги пророка Исаии (42: 24), разбитой в оригинале на две части и обрамленной пояснениями:

\begin{tabular}{|c|c|}
\hline $\begin{array}{l}\text { Veram exclamare licet cum Propheta: Quis } \\
\text { det in direptionem Iacob et Israel vastantibus? } \\
\text { nonne Dominus cui peccavimus? Ita est plane; } \\
\text { longanimem Dei patientiam proritant hominum } \\
\text { flagitia, eiusque vindictam accersunt: nam, ut } \\
\text { subiungit idem Propheta: Noluerunt in viis suis } \\
\text { ambulare, nec audiverunt legem eius, et effudit } \\
\text { super eum indignationem furoris sui, et forte } \\
\text { bellum... (Breve 1672. P. } 364 \text { ). }\end{array}$ & $\begin{array}{l}\text { Истинно возопити леть есть со пророком, кто даде } \\
\text { в пленение Иякова, и Исраиля поразушим, } \\
\text { или не Господь, емуже согрешихом. Сиџе есть } \\
\text { поистинне, долготерпеливое Божие терпение, } \\
\text { движають прегрешения человеков, и его же } \\
\text { отмшения призовут, ибо яко ниже пишет тойжде } \\
\text { пророк, не хотяху в пути его путь шествовать, } \\
\text { ниже услышаху закони его и излия на них } \\
\text { ярость гнева своего, и негли брань... (Грамота } \\
\text { 1672. С. 141). }\end{array}$ \\
\hline
\end{tabular}

Комментария заслуживают два любопытных факта. Прежде всего, способ передачи коммуникативных микроконтекстов оригинала:

восклищая («Veram exclamare licet») вместе с пророком первую часть џитаты, автор латинского бреве после морального метатекста присоединяет-озвучивает («ut subiungit idem Propheta») вторую ее часть; 
восклицая ( «истинно возопити леть есть») вместе с пророком, переводчик затем указывает на продолжение цуитаты в тексте Библии («ибо яко ниже пишет тойжде пророк»), однако сам не стремится воспроизвести авторитетный текст (ср. «кто даст на разграбление Иакова, и Израиля пленяюшым его, не Бог ли убо, емуже согрешиша, и не изволиша в пути его ходити, ни послушати закона его. И наведе на ня гнев ярости своея, и укрепи на ня рать» (Московская Библия 1663 г.)), но переводит заново с папского бреве.

Возможно, ссылка в латинском подлиннике на безымянного пророка не позволила переводчику понять, что речь идет именно об Исаие, а џитированный отрывок не был широко известным текстом, позволяющим сразу установить его происхождение и обратиться к уже сушествуюшему переводу.

В свою очередь, в формуле «et forte bellum» лексема forte была понята переводчиком как наречие 'по случаю', эквивалентом к которому была выбрана частиџа «негли» со значением ‘может быть, пожалуй’ (функџиональный вариант значения - противительно-отриџательный союз «а не» $\left.{ }^{27}\right)$. Тем самым возникшй̈ переводной контекст может быть истолкован: «излил на них гнев ярости своей, а при случае [по необходимости] - и брань» или с усилительнопротивительным оттенком: «а может быть, даже и брань», «а не дай Бог и брань».

Переводчик не почувствовал еше одну библейскую аллюзию, скрытую в тексте грамоты. Так, отрывок «еt induat fortitudine quae de caelo est, ut hostes nostros, qui in multitudine...» ${ }^{28}$, явно указывающий на 1 Макк 3: 19, переведенный в Московской Библии 1663 г. как «яко не во множестве вои одоления брани есть, но от небесе крепость», у русского переводчика папского бреве превратился в «и да облечет державою еже ревности ради вера бывает» ${ }^{29}$.

Суммируя сказанное, подчеркнем, что перевод папского бреве 5 ноября 1672 г. свидетельствует скорее о достаточной квалификаџии переводчика, большинство же ошибок и темных мест перевода следует отнести на счет спеџифического содержания (џерковные юбилейные мероприятия) и витиеватого риторического устройства и стиля послания, а также, весьма вероятно, на ускоренные темпы работы переводчика.

Юбилейное ноябрьское бреве папы Климента $X$, вызванное взятием султанской армией в августе-сентябре 1672 г. Каменџа-Подольского, сходно по своей структуре с бреве папы Александра VII 2 марта 1661 г., объявляюшим «Jubileum universale ad implorandam divinam opem contra Turcas» ${ }^{30}$. Бреве 1672 г., в свою очередь, послужило структурным и стилистическим образцом для аналогичной юбилейной грамоты 11 августа 1683 г. папы Иннокентия XI «Litterae Apostolicae Innocentii XI, quibus indicitur Iubilaeum universale ad implorandam divinam opem contra Turcas», отозвавшейся на осаду Вены турками в июле-августе 1683 г. и на месяџ предварившей освобождение города союзными христианскими силами ${ }^{31}$.

Оба последних бреве характеризует сходная композиџия: изложение обстоятельств объявления юбилея, указание - соответственно в 1672 и 1683 г. - Речи Посполитой / Священной Римской империи, Каменџа Подольского / Вены как ключевых пунктов европейского

27 Словарь русского языка XI-XVII вв. М., 1986. Вып. 11. С. 65-66.

${ }^{28}$ Breve 1672. P. 364.

29 Грамота 1672. С. 145. При этом сам текст можно считать более узнаваемым, чем џитата из Книги пророка Исаии. Так, архимандрит Новоспасского монастыря Игнатий Римский-Корсаков џитировал в своем «Слове к благочестивому и христолюбивому воинству» $(1687$ г.), произнесенном в связи с походом на Крым: «Несть разньства пред Богом небесным, спасти во мнозе и в мале, яко не во множестве вой одоления брани есть, но от небесе крепость!» (Памятники общественно-политической мысли в России конџа XVII века: Литературные панегирики / Подготовка текста, предисл. и коммент. А. П. Богданова. М., 1983. Кн. 1. С. 158).

${ }_{30}$ Magnum Bullarium romanum. Vol. 6. P. 141-142.

31 Acta Sanctae Sedis in compendium opportune redacta et illustrata / Studio et cura Iosephi Pennacchi et Victorii Piazzesi. Romae, 1906. Vol. XVI. P. 58-63.

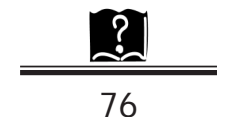


политического проџесса (в бреве 1683 г. также упомянуты «возлюбленные во Христе сыны»император Леопольд и Ян Собеский); перечисление юбилейных мероприятий и условий индульгенџий.

Обшие места характеризуют обе папские грамоты в тех частях, где описывается:

ужасаюший облик восточного агрессора:

\begin{tabular}{|c|c|}
\hline $\begin{array}{l}\text {...de florentissimi olim Poloniae regni rebus } \\
\text { formidabili Turcarum potentia atque immanitate } \\
\text { summum in discrimen adductis corde iugiter } \\
\text { versamus... (Breve 1672. P. 364). }\end{array}$ & $\begin{array}{l}\text { Civitatum, oppidorum, et agrorum excidia, } \\
\text { vastationes, direptiones, et incendia, aliaque } \\
\text { innumera mala, quibus nefarius Turcarum Tyrannus, } \\
\text { immani ferocia, formidabilique sua potentia nomen } \\
\text { Christianum delere molitur. (Breve 1683. P. 58). }\end{array}$ \\
\hline $\begin{array}{l}\text { Expugnata siquidem nuper Camenecia, quae } \\
\text { infensissimorum christiani nominis hostium } \\
\text { impetus non semel cohibuerat atque fregerat, } \\
\text { immitis Turcarum tyrannus, eo successu inflatus } \\
\text { pro inexplebili, qua flagarat, dominandi imperiique } \\
\text { sui pomoeria proferendi libidine, victricia arma } \\
\text { quaquaversum circumferre, arces, oppida, civitates } \\
\text { et provincias debellare, populos servitute opprimere, } \\
\text { et miserandam in captivitatem adducere, ac } \\
\text { Mahumetanae perfidiae abominationem, vi, terrore, } \\
\text { dolo, omnique conatu in agro Dei viventis plantare } \\
\text { non cessat... (Breve } 1672 \text {. P. } 364 \text { ). }\end{array}$ & $\begin{array}{l}\text { Immitis enim ille Tyrannus secundis armorum } \\
\text { suorum initiis inflatus, nihilque sibi impervium } \\
\text { iam fore confidens, Viennam Austriae, Urbem } \\
\text { celeberrimam, ac munitissimam, et quae tumentes } \\
\text { olim Turcicorum armorum fluctus confregit, arcta } \\
\text { vehementique obsidione oppugnat, et tanquam } \\
\text { inexplebilis bellua Christianas omnes Provincias } \\
\text { spe iam devorat, Mahumetanaque perfidia } \\
\text { abominationem longe lateque propagare, ac Dei } \\
\text { viventis Ecclesiam funditus destruere satagit... } \\
\text { (Breve 1683. P. 58). }\end{array}$ \\
\hline
\end{tabular}

планы юбилейных џеремоний и проџессий:

Nos enim de omnipotentis Dei misericordia ac beatorum Petriet Pauli Apostolorum eius auctoritate confisi, ex illa ligandi, et solvendi potestate, quam nobis Dominus, licet indignis, contulit, universis, et singulis utriusque sexus Christi fidelibus in alma Urbe nostra degentibus, qui solemni processioni, quam aliqua die proximae venturae hebdomadae ab ecclesia S. Mariae supra Minervam ad ecclesiam S. Stanislai nationis Polonorum de eadem Urbe (Breve 1672. P. 365).
Itaque de omnipotentis Dei misericordia, ac beatorumPetri,etPauliApostolorumeiusauthoritate confisi, ex illa ligandi, et solvendi potestate, quam Nobis Dominus, licet indignis, contulit, universis, et singulis utriusque sexus Christi fidelibus in alma Urbe nostra degentibus, qui solemni processioni, quam aliqua die proxime venturae hebdomadae ab Ecclesia Sanctae Mariae super Minervam ad Ecclesiam eiusdem sanctae Mariae de Anima nuncupatam Nationis Theutonicorum de eadem Urbe (Breve 1683. P. 60).

Подобно тому, как бреве 5 ноября 1672 г. папы Климента $\mathrm{X}$ не оставило равнодушной всю христианскую Европу - вплоть до Москвы, центра Pax Slavia Orthodoxa XVII столетия, бреве 11 августа 1683 г. папы Иннокентия XI также не прошло незамеченным в славянском мире. В частности, чешский капеллан Эвермод Иржи Кошетиџкий скопировал на листах 358b-360b своего рукописного сборника «Quodlibetica» (начат в 1680 г.) среди современных ему чешских, немеџких и латинских духовных опусов и театральных пьес, курьезных стихов и злободневных памфлетов также «Sanctissimi D. N. D. Innocentii, divina providentia Papae XI., jubilaeum universale ad implorandam divinam opem contra Turcas. Opis přislušneho latinskeho listu řečeneho papeže ze dne 11. srpna r. $1683 »^{32}$.

32 Podlaha A. Rukopisný sborník Evermonda Jiř́ho Košetického // Sborník Historického kroužku. 1904. Ročnik V. S. 121.

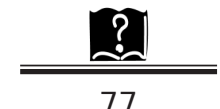


Переведенные или скопированные в славянских странах папские бреве с призывами к борьбе против султана, таким образом, представляют собой следы усилий дипломатии римской курии по объединению европейских стран для сопротивления экспансии Османской империи и включению в этот союз также Slavia Orthodoxа во имя зашиты Res publica Christiana. Впрочем, межгосударственные противоречия позволили реализовать эти планы лишь отчасти, и задуманная широкая антиосманская коалиџия, сформированная с большим трудом, просуџествовала недолго.

\section{Литература}

Корнилаева И. А., Кузнецова А. В., Шамин С. М. Неизвестный перевод грамоты папы Климента Х // Труды Института русского языка имени В. В. Виноградова. 2015. Вып. 5. С. 127-148.

Лихачев $Н$. П. Письмо папы Пия $\mathrm{V}$ к царю Ивану Грозному в связи с вопросом о папских бреве. Этюд о дипломатике пап. СПб., 1906. [1], 175 с.

Усков Н. СD. «Annus sanctus» // Православная энџиклопедия. М., 2000. Т. 2. С. 469-470.

с Флоря Б. Н. Войны Османской империи с государствами Восточной Европы (1672-1681 гг.) // Османская империя и страны Џентральной, Восточной и Юго-Восточной Европы в XVII в. М., 2001. Ч. 2. C. $108-148$.

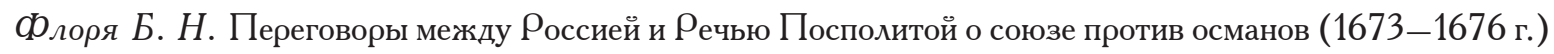
// Древняя Русь. Вопросы медиевистики. 2017. № 1 (67). С. 61-75.

Ф медиевистики. 2018. № 1 (71). С. 74-88.

Чарыков Н. В. Посольство в Рим и служба в Москве Павла Менезия (1637-1694). СПб., 1906. Х, 776, II c.

Шамин С. М. Известия греческих информаторов о действиях Османской империи и ее союзников в Речи Посполитой в 1672-1673 гг. (По материалам фонда 155 РГАДА) / / Каптеревские чтения. М., 2009. Вып. 7. С. 202-208.

Шамин С. М. Куранты XVII столетия. Европейская пресса в России и возникновение русской периодической печати. М.; СПб., 2011. 347, [1] с.

Corsi D. Lettere di Giovanni Sobieski a Francesco Buonvisi // Bollettino storico lucchese. 1940. Anno 12. № 1. P. 25-42.

Davies B. L. Warefare, State and Society on the Black Sea Steppe, 1500-1700. London; New York, 2007. $256 \mathrm{p}$.

Kołodziejczyk D. Podole pod panowaniem tureckim. Ejalet Kamieniecki. 1672-1699. Warszawa, 1994. 255 s. Kotodziejczyk D. The Ottoman Survey Register of Podolia (ca. 1681). Defter-iMufassal-i Eyalet-iKamaniçe. Kyiv; Cambridge (Mass.), 2004. Pt. 1: Text, Translation, and Commentary. 672 p.

Ostapchuk V. Cossack Ukraine In and Out of Ottoman Orbit, 1648-1681 / The European Tributary States of the Ottoman Empire in the Sixteenth and Seventeenth Centuries. Leiden; Boston, 2013. P. 123-152.

Petrocchi M. La politica della Santa Sede di fronte all'invasione ottomana (1444-1718). Napoli, 1955. 118 p. Şakul K. Siege Warfare in Verse and Prose: the Ottoman Conquest of Kamianets-Podilsky (Kamaniçe), 1672 // The World of the Siege. Representations of Early Modern Positional Warfare. Leiden; Boston, 2019. P. 205-240.

Thurston H. The Holy year of Jubilee. An Account of the History and Ceremonial of the Roman Jubilee. London, $1900.420 \mathrm{p}$.

Trevellini A. M. Il cardinale Francesco Buonvisi, nunzio a Vienna (1675-1689). Firenze, 1958. 152 p.

Wagner M. Wojna polsko-turecka w latach 1672-1676. Zabrze, 2009. T. 1. 408 s.

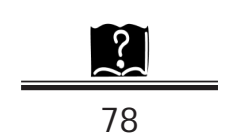




\section{References}

Charykov, N. V. Posol'stvo v Rim i sluzhba v Moskve Pavla Meneziya (1637-1694) [The Embassy in Rome and Service in Moscow of Paul Menzies (1637-1694)]. SPb., 1906. X, 776, II p.

Corsi, D. Lettere di Giovanni Sobieski a Francesco Buonvisi. In Bollettino storico lucchese. 1940. Anno 12. № 1. P. 25-42.

Davies, B. L. Warefare, State and Society on the Black Sea Steppe, 1500-1700. London; New York, 2007. $256 \mathrm{p}$.

Florya, B. N. Voiny Osmanskoi imperii s gosudarstvami Vostochnoi Evropy (1672-1681 gg.) [Wars of the Ottoman Empire with the States of Eastern Europe (1672-1681)]. In Osmanskaya imperiya istrany Tsentral'noi, Vostochnoi i Yugo-Vostochnoi Evropy v XVII v. M., 2001. Ch. 2. P. 108-148.

Florya, B. N. Peregovory mezhdu Rossiei i Rech'yu Pospolitoi o soyuze protiv osmanov (1673-1676 g.) [Negotiations between Russia and The Polish-Lithuanian Commonwealth on an Alliance against the Ottomans (1673-1676)]. In Drevnyaya Rus'. Voprosy medievistiki. 2017. № 1 (67). P. 61-75.

Florya, B. N. Pokhod osmanov na Rech' Pospolituyu v 1672 g. i Rossiya [Ottoman Campaign on the PolishLithuanian Commonwealth in 1672 and Russia]. In Drevnyaya Rus'. Voprosy medievistiki. 2018. № 1 (71). P. 74-88.

Kołodziejczyk, D. Podole pod panowaniem tureckim. Ejalet Kamieniecki. 1672-1699. Warszawa, 1994. $255 \mathrm{~s}$.

Kołodziejczyk, D. The Ottoman Survey Register of Podolia (ca. 1681). Defter-iMufassal-i Eyalet-iKamaniçe. Kyiv; Cambridge (Mass.), 2004. Pt. 1: Text, Translation, and Commentary. 672 p.

Kornilaeva, I. A., Kuznetsova, A. V., Shamin, S. M. Neizvestnyi perevod gramoty papy Klimenta X [The Unknown Translation of the Letter of the Pope Clement X]. In Trudy Instituta russkogo yazyka imeni V. V. Vinogradova. 2015. Vyp. 5. P. 127-148.

Likhachev, N. P. Pis'mo papy Piya V k tsaryu Ivanu Groznomu v svyazi s voprosom o papskikh breve. Etyud o diplomatike pap [The Letter from Pope Pius V to Tsar Ivan the Terrible in connection with the Question of Papal Breve. Etude on Popes' Diplomacy]. SPb., 1906. [1], 175 p.

Ostapchuk, V. Cossack Ukraine In and Out of Ottoman Orbit, 1648-1681. In The European Tributary States of the Ottoman Empire in the Sixteenth and Seventeenth Centuries. Leiden; Boston, 2013. P. 123-152.

Petrocchi, M. La politica della Santa Sede di fronte all'invasione ottomana (1444-1718). Napoli, 1955. $118 \mathrm{p}$.

Shamin, S. M. Izvestiya grecheskikh informatorov o deistviyakh Osmanskoi imperii i ee soyuznikov v Rechi Pospolitoi v 1672-1673 gg. (Po materialam fonda 155 RGADA) [News of Greek Informants about the Actions of the Ottoman Empire and Its Allies in the Polish-Lithuanian Commonwealth in 1672-1673 (Based on the Materials of the Fund 155 of the Russian State Archive of Ancient Acts)]. In Kapterevskie chteniya. M., 2009. Vyp. 7. P. 202-208.

Shamin, S. M. Kuranty XVII stoletiya. Evropeiskaya pressa v Rossii i vozniknovenie russkoi periodicheskoi pechati [Kuranty of the $17^{\text {th }}$ Century. European Press in Russia and the Emergence of the Russian Periodical Press]. M.; SPb., 2011.347, [1] p.

Şakul, K. Siege Warfare in Verse and Prose: the Ottoman Conquest of Kamianets-Podilsky (Kamaniçe), 1672. In The World of the Siege. Representations of Early Modern Positional Warfare. Leiden; Boston, 2019. P. 205-240.

Thurston, H. The Holy year of Jubilee. An Account of the History and Ceremonial of the Roman Jubilee. London, $1900.420 \mathrm{p}$.

Trevellini, A. M. Il cardinale Francesco Buonvisi, nunzio a Vienna (1675-1689). Firenze, 1958. 152 p.

Uskov, N. F. "Annus sanctus". In Pravoslavnaya entsiklopediya. M., 2000. T. 2. P. 469-470.

Wagner, M. Wojna polsko-turecka w latach 1672-1676. Zabrze, 2009. T. 1. 408 s.

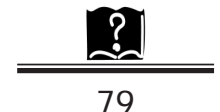




\author{
Sergey V. Alpatov \\ Lomonosov Moscow State University, Moscow, Russia \\ Vera G. Tchentsova \\ UMR 8167 Orient et Méditerranée / Monde byzantin, Paris, France / Maison française d'Oxford
}

\title{
A RUSSIAN TRANSLATION OF THE PAPAL BRIEF PROCLAIMING 1672 \\ AS A JUBILEE YEAR OF MERCY
}

The article presents historical context of publication of the papal brief (breve) of 1672, possible ways of its diffusion into Eastern Europe, political significance of the document for organisation of an anti-Ottoman coalition, and linguistic particularities of the Russian translation of the Latin text.

Keywords: breve, jubilee, pope Clement X, Russian translation, Ottoman conquest of Kamieniec-Podolsk 